\title{
PENGARUH GAYA KEPEMIMPINAN KEPALA SEKOLAH DAN PARTISIPASI KOMITE SEKOLAH TERHADAP KINERJA GURU SMK SEKECAMATAN LABUHAN MARINGGAI LAMPUNG TIMUR
}

\author{
Muhamad Zainul Anwar ${ }^{1}$,Marzuki Noor ${ }^{2}$, Riyanto ${ }^{3 *}$ \\ ${ }^{1}$ SMK Muhammadiyah 1 Labuhan Maringgai Lampung \\ ${ }^{23 *}$ Universitas Muhammadiyah Metro, Metro, Indonesia \\ Email : smkmugad@gmail.com ${ }^{1)}$ \\ marzuki@yahoo.com ${ }^{2)}$ \\ riyantoto56@gmail.com ${ }^{3)^{*}}$
}

\begin{abstract}
Abstrak
Tujuan penelitian adalah untuk mendeskripsikan dan menganalisa 1) pengaruh gaya kepemimpinan kepala sekolah terhadap kinerja guru, 2) partisipasi komite sekolah terhadap kinerja guru, 3) pengaruh gaya kepemimpinan kepala sekolah dan partisipasi komite sekolah secara bersama-sama terhadap kinerja guru SMK Se-Kecamatan Labuhan Maringgai Lampung Timur. Jenis penelitian deskriptif kuantitatif, yang unsur-unsurnya terdiri atas kepala sekolah, komite sekolah dan guru. Pengumpulan data menggunakan cross section dengan menggunakan media kuisioner atau angket serta analisis data menggunakan regresi. Dengan gaya kepemimpinan kepala sekolah dapat menentukan keberhasilan atau kegagalan guru dalam menjalankan tugas. Hasil penelitian ini menunjukkan bahwa pengaruh gaya kepemimpinan kepala sekolah berpengaruh nyata terhadap kinerja guru, hal ini bermakna bahwa karena gaya kepemimpinan kepala sekolah menjalankan gaya kepemimpinannya dengan baik, maka kinerja guru juga mengalami peningkatan. Hasil penelitian mengungkap partisipasi komite sekolah berpengaruh langsung terhadap kinerja guru, karena partisipasi komite sekolah dijalankan dengan baik, maka kinerja guru juga mengalami peningkatan. Pengaruh Gaya kepemimpinan kepala sekolah dan partisipasi komite sekolah secara bersama-sama berpengaruh secara signifikan terhadap kinerja guru, karena gaya kepemimpinan kepala sekolah dilaksanakan dengan baik dan partisipasi komite sekolah dilaksanakan dengan baik, kinerja guru juga mengalami peningkatan.
\end{abstract}

Kata Kunci: kepemimpinan kepala sekolah, komite sekolah, kinerja guru

\begin{abstract}
The purpose of the study was to describe and analyze 1) the effect of the principal's leadership style on teacher performance, 2) the participation of the school committee on teacher performance, 3) the effect of the principal's leadership style and the participation of the school committee together on the performance of teachers in SMK in Labuhan District. Maringgai, East Lampung. This type of quantitative descriptive research, whose elements consist of principals, school committees and teachers. Collecting data using a cross section using a media questionnaire or questionnaire and data analysis using regression. The principal's leadership style can determine the success or failure of teachers in carrying out their duties. The results of this study indicate that the influence of the principal's leadership style has a significant effect on teacher performance, this means that because the principal's leadership style carries out his leadership style well, the teacher's performance also increases. The results of the study reveal that school committee participation has a direct effect on teacher performance, because school committee participation is carried out well, teacher performance also increases. The influence of the principal's leadership style and school committee participation together has a significant effect on teacher performance, because the principal's leadership style is implemented well and school committee participation is carried out well, teacher performance also increases.
\end{abstract}

Keywords: the principal's leadership, the school committee, the teacher's performance. 


\section{PENDAHULUAN}

Pendidikan merupakan wujud dari usaha untuk menumbuhkan dan meningkatkan mutu sumber daya manusia menuju era yang penuh dengan tantangan, maka pendidikan adalah suatu yang sangat fundamental untuk setiap individu, karena pendidikan begitu penting dalam menjamin perkembangan dan keberlangsungan kehidupan bangsa. Problematika pendidikan adalah hal penting dalam kehidupan keluarga, bangsa dan negara. Maju dan mundurnya suatu bangsa dan negara sebagian besar ditentukan oleh maju mundurnya pendidikan.

Kinerja guru banyak dikaitkan dengan rendahnya mutu pendidikan. Guru merupakan makhluk sosial yang juga memerlukan kebutuhan yang lain untuk dapat bekerja dengan baik. Faktor internal adalah faktor dari dalam diri guru itu sendiri, Antara lain motivasi kerja dan kompetensi guru. Faktor eksternal, antara lain, lingkungan, baik lingkungan keluarga maupun lingkungan kerja. Lingkungan kerja, Antara lain, hubungan sesama guru, kepala sekolah, komite sekolah dan seluruh stakeholder sekolah. Jika diamati di lapangan, guru telah menunjukkan kinerja maksimal dalam menjalankan tugas dan fungsinya sebagai pendidik, pengajar dan pelatih namun masih ada sebagian guru yang belum menunjukkan kinerja baik yang tentunya akan berpengaruh terhadap kinerja guru secara makro.

Peran dan fungsi komite sekolah sebaiknya bukan hanya difokuskan pada pengembangan kondisi fisik sekolah melalui pertemuan, namun lebih kepada pengembangan kualifikasi siswa dan guru bidang akademik salah satunya sebagai mediator antara sekolah dan masyarakat. Peran serta masyarakat dalam penyelenggaraan pendidikan sebatas pada dukungan dana, sedang dukungan-dukungan lain seperti pemikiran, moral dan barang atau jasa kurang diperhatikan.

Akuntabilitas sekolah terhadap masyarakat juga lemah. Sekolah tidak mempunyai beban untuk mempertanggungjawabkan hasil pelaksanaan pendidikan kepada masyarakat, khususnya orang tua siswa, sebagai salah satu unsur utama yang berkepentingan dengan pendidikan. Permasalahan yang muncul dalam pertisipasi komite sekolah di SMK Se-Kecamatan Labuhan Maringgai Lampung Timur yaitu komite sekolah belum sepenuhnya menjalankan perannya dan komite sekolah tidak aktif dalam perkembangan sekolah.

Kinerja guru adalah hasil kerja yang dapat dicapai oleh seorang guru di SMK Sekecamatan Labuhan Maringgai sesuai tugas dan tanggung jawabnya dalam mencapai tujuan pendidikan. Dengan kata lain, hasil kerja yang dicapai seseorang dalam melaksanakan tugas-tugas yang dibebankan kepadanya didasarkan atas kecakapan, pengalaman, dan kesungguhan.

Kinerja guru juga dapat terlihat melalui sebuah penilaian melalui angket. Namun, untuk mendapatkan hasil yang optimal penilaian angket yang dilakukan pun harus seobjektif mungkin, teliti, dan tepat. Aspek yang dinilai pun perlu diperhitungkan dan dikaji dengan baik sehingga hasil penilaian mampu menjadi motivasi bagi guru untuk terus meningkatkan kinerjanya. Adapun yang menjadi salah satu faktor yang menyebabkan kualitas kerja guru menurun adalah kurangnya pengawasan dari kepala sekolah. Kinerja guru masih rendah dipengaruhi oleh beberapa faktor.

Kepemimpinan kepala sekolah belum optimal sehingga tujuan pendidikan belum tercapai dan terwujud dari hasil belajar siswa yang kurang. Peran komite sekolah juga merupakan bentuk pelayanan dengan memberikan pertimbangan, arahan dan dukungan tenaga, sarana dan prasarana. Komite sekolah harus mengembangkan kinerja, membentuk program kerja sebagai pegangan dalam menjalankan peran, tugas, dan 
fungsinya sesuai aturan yang telah diterapkan. Semakin baik pengontrol peran komite sekolah maka semakin baik kinerja guru.

Kinerja guru dipengaruhi oleh berbagai faktor antara lain ; kepribadian, pengembangan profesi, kemampuan mengajar, hubungan dengan masyarakat, kedisiplinan, kesejahteraan, iklim kerja. Diantara faktor tersebut ada yang berasal dari dalam diri guru sendiri misalnya kedisiplinan mengajar, motivasi mengajar, dan tanggung jawab dalam pelaksanaan tugas pembelajaran.

Menurut Undang-Undang No.14 Tahun 2005 tentang Kinerja Guru menunjukan bahwa guru berkewajiban menyedian perangkat pembelajaran secara baik. Yaitu :

1. Merencanakan pembelajaran, melaksanakan proses pembelajaran yang bermutu, serta menilai dan mengevaluasi hasil pembelajaran;

2. Meningkatkan dan mengembangkan kualifikasi akademik dan kompetensi secara berkelanjutan sejalan dengan perkembangan ilmu pengetahuan, teknologi, dan seni;

3. Bertindak objektif dan tidak diskriminatif atas dasar pertimbangan jenis kelamin, agama, suku, ras, dan kondisi fisik tertentu, atau latar belakang keluarga, dan status sosial ekonomi peserta didik dalam pembelajaran;

4. Menjunjung tinggi peraturan perundang-undangan, hukum, dan kode etik guru, serta nilai-nilai agama dan etika; dan

5. Memelihara dan memupuk persatuan dan kesatuan bangsa

Selain faktor internal terdapat pula faktor ekternal yang diduga mempengaruhi kinerja guru, misalnya tentang gaya kepemimpinan, dan komite sekolah. Gaya kepemimpinan adalah perilaku yang ditunjukkan seseorang pada saat ia mempengaruhi perilaku orang lain. Gaya Kepemimpinan kepala sekolah harus bertanggung jawab menjaga dan memotivasi guru, peserta didik, dan staf administrasi sekolah agar mau melaksanakan ketentuan dan peraturan yang berlaku disekolah.

Gaya kepemimpinan kepala sekolah yang sering diterapkan oleh setiap kepala sekolah dalam mencapai tujuan sekolah pada umumnya menggunakan gaya delegatif dimana kepala sekolah sering melimpahkan tugas dan wewenang untuk menjalankan sebagian tugas kepala sekolah dengan gaya delegatif. Selain gaya delegatif kepala sekolah ada pula yang menerapkannya dengan gaya konsultatif ketika terdapat guruguru yang kemampuan atau pengetahuannya rendah namun memiliki kemauan untuk melaksanakan kegiatan pembelajaran maupun kegiatan extra lainnya dengan penuh semangat.

Selain menerapkan gaya delegatif dan konsultatif adakalanya guru memiliki kemampuan berpikir yang tinggi namun adakalanya memiliki sifat malas atau dengan kata lain kemauan untuk mengajar rendah misalnya membolos, sering tidak masuk kelas, mengajar tidak tepat waktu dan lain sebagainya. Sebagai kepala sekolah yang memiliki penerapan gaya kepemimpinan dalam memimpin lembaga atau sekolahnya. Ada juga guru yang tingkat kemampuan dan kemauannya untuk melaksanakan tugas pembelajaran relatif rendah. Untuk kelompok guru ini gaya memimpin yang cocok diterapkan adalah gaya instruktif. Permasalahan di atas diduga terjadi pula di SMK Sekecamatan Labuhan Maringgai Kabupaten Lampung Timur.

Berdasarkan uraian permasalahan yang ada menunjukkan bahwa kualitas kinerja guru yang masih rendah. Gaya kepemimpinan kepala sekolah yang baik akan menciptakan lingkungan kerja yang baik pula, oleh karena itu dapat dijelaskan bahwa 
lingkungan kerja yang baik juga akan mempengaruhi kinerja pendidik, sehingga mampu mencapai tujuan yang diharapkan.

Gaya kepemimpinan kepala sekolah, partisipasi komite sekolah dan kinerja guru sangat menarik untuk diteliti. Penelitian ini dilaksanakan untuk mengetahui "Pengaruh gaya kepemimpinan kepala sekolah dan partisipasi komite sekolah terhadap kinerja guru di SMK Sekecamatan Labuhan Maringgai Kabupaten Lampung Timur”.

Berdasarkan hasil pra survei yang dilakukan penulis dari tanggal 7 sampai dengan tanggal 12 Oktober 2019 di SMK Se Kecamatan Labuhan Maringgai, yaitu SMK Muhammadiyah 1 Labuhan Maringgai, SMK Negeri 1 Labuhan Maringgai, dan Sekolah SMK Darul Hidayah Labuhan Maringgai dengan cara melakukan wawancara bersama dengan beberapa orang guru dan wakil kepala sekolah bidang kurikulum pada masing-masing sekolah, sehingga diperoleh hasil data pra survey sebagai berikut:

Tabel 1. Data Kinerja Guru SMK Se Kecamatan Labuhan Maringgai

\begin{tabular}{c|l|l}
\hline No & \multicolumn{1}{|c}{ Indikator } & \multicolumn{1}{c}{ Kesenjangan } \\
\hline 1 & $\begin{array}{l}\text { Guru yang memiliki kemampuan } \\
\text { menyusun rencana pembelajaran }\end{array}$ & $\begin{array}{l}\text { Banyaknya guru yang belum mampu } \\
\text { menyusun rencana pembelajaran. }\end{array}$ \\
\hline 2 & $\begin{array}{l}\text { Guru yang memiliki kemampuan } \\
\text { memilih media pembelajaran }\end{array}$ & $\begin{array}{l}\text { Banyak Guru yang belum mampu } \\
\text { menggunakan media. }\end{array}$ \\
\hline 3 & $\begin{array}{l}\text { Guru yang memiliki kemampuan } \\
\text { menerapkan strategi belajar yang } \\
\text { bervariasi }\end{array}$ & $\begin{array}{l}\text { Guru yang memiliki kemampuan } \\
\text { menggunakan bentuk dan jenis ragam } \\
\text { penilaian }\end{array}$ \\
\hline 4 & $\begin{array}{l}\text { Guru yang memiliki kemampuan guru yang hanya mengunakan } \\
\text { memerikasa dan menganalisis penilaian }\end{array}$ & $\begin{array}{l}\text { Banyak Guru yang masih sering } \\
\text { melakukan penilaian baru secara } \\
\text { subjektif. }\end{array}$ \\
\hline 5 & $\begin{array}{l}\text { Guru yang memiliki kemampuan guru yang belum mampu } \\
\text { melaksanakan program tindak lanjut }\end{array}$ & $\begin{array}{l}\text { Lemahnya guru dalam pelaksanaan } \\
\text { program tindak lanjut. }\end{array}$ \\
\hline \multicolumn{2}{|c|}{ Sumber data: diolah dari Hasil Pra Survei Tanggal 7 - 12 Oktober 2019 }
\end{tabular}

Berdasarkan tabel data hasil pra survei di atas dapat dilihat bahwa terdapat kesenjangan antara target dengan capaian pada masing-masing indikator. Pada aspek guru yang memiliki kemampuan menyusun rencana pembelajaran dengan target $100 \%$ ternyata hasil pra survey diperoleh capaian 57\% sehingga terdapat kesenjangan $43 \%$. Pada aspek guru yang memiliki kemampuan memilih media pembelajaran dengan target $100 \%$ ternyata hasil pra survey diperoleh capaian $60 \%$ sehingga terdapat kesenjangan 40\%. Pada aspek guru yang memiliki kemampuan menerapkan strategi belajar yang bervariasi dengan target $100 \%$ ternyata hasil pra survey diperoleh capaian $63 \%$ sehingga terdapat kesenjangan 37\%. Pada aspek guru yang memiliki kemampuan menggunakan bentuk dan jenis ragam penilaian dengan target $100 \%$ ternyata hasil pra survei diperoleh capaian 53\% sehingga terdapat kesenjangan 47\%. Pada aspek guru yang memiliki kemampuan memeriksa dan menganalisis penilaian dengan target $100 \%$ ternyata hasil pra survey diperoleh capaian $42 \%$ sehingga terdapat kesenjangan $58 \%$. Dan pada aspek guru yang memiliki kemampuan melaksanakan program tindak lanjut dengan target $100 \%$ ternyata hasil pra survey diperoleh capaian 39\% sehingga terdapat kesenjangan 61\%. Dan apabila merujuk pada Peraturan Menteri Negara Pendayagunaan Aparatur Negara dan Reformasi Birokrasi Nomor 16 Tahun 2009 terdapat beberapa indikator kinerja yang nilainya di bawah 50 atau dengan kategori rendah. Sehingga 
dapat diduga bahwa ada masalah dalam hal kinerja guru sekolah menengah kejuruan negeri.

Selain data di atas, juga dijelaskan temuan-temuan yang menjadi kendala pada sekolah-sekolah tersebut. Pertama, kompetensi yang dimiliki guru masih terbilang rendah. Hal ini ditunjukkan dalam penyusunan perangkat pembelajaran belum sesuai dengan petunjuk teknis penyusunan. Seperti pengembangan silabus dan Rencana Pelaksanaan Pembelajaran (RPP) masih diambil dari internet dan copy paste. Bahkan tidak sedikit guru yang belum mampu membuat rencana pembelajaran dengan benar. Pelaksanaan pembelajaran yang masih monoton, sehingga memberikan kesan kepada peserta didik hanya sekedar menggugurkan kewajiban. Kualitas pembelajaran yang masih rendah memaksa siswa untuk tidak tertarik terhadap proses pembelajaran di kelas, karena guru belum mampu menyusun atau membuat model dan strategi belajar yang bervariasi. Pengembangan penilaian yang belum sesuai dengan karakteristik peserta didik serta tindak lanjut yang belum sepenuhnya dilaksanakan dengan baik dan benar. Kedua, kepala sekolah belum menerapkan gaya kepemimpinan yang tepat, seperti belum adanya kemampuan dalam membangun komunikasi kepada bawahan, belum mampu membangun kebersamaan, belum mampu memberi pengarahan yang jelas dan kepala sekolah belum nampak memberikan dukungan dalam kerja. Ketiga, partisipasi komite sekolah masih kurang, seperti masih kurang terlibat dalam proses pembelajaran, pengadaan sarana dan prasarana yang masih minim dan belum terlibat secara maksimal memfasilitasi memperoleh kerjasama peduli pendidikan.

\section{METODE PENELITIAN}

\section{Rancangan Penelitian}

Penelitian ini adalah bersifat kuantitatif yaitu menguji kausalitas (pengaruh) variabel bebas terhadap variabel terikat berlandaskan teori pendukung setiap variabel. Variabel yang dicari pengaruhnya dalam adalah variabel bebas yaitu gaya kepemimpinan $\left(\mathrm{X}_{1}\right)$, partisipasi komite sekolah $\left(\mathrm{X}_{2}\right)$, dan variabel terikat kinerja $\operatorname{guru}(\mathrm{Y})$.

\section{Populasi Penelitian dan Sampel}

Populasi dalam penelitian ini merupakan guru SMK se-Kecamatan Labuhan Maringgai Lampung Timur yang berjumlah 95 orang. Berdasarkan hasil penetapan sampel diatas, maka teknik pengambilan sampel menggunakan Claster Proporsional Random Sampling, dengan cara undian. Adapun langkah-langkah yang digunakan dalam penetapan sampel yang telah ditetapkan adalah sebagai berikut:

a. Seluruh anggota populasi (95 populasi) ditulis dalam kertas ukuran $3 \times 5$ untuk dilakukan undian dengan pengambilan acak;

b. Menggulung kertas yang telah berisi nama-nama anggota populasi, kemudian dimasukkan kedalam wadah tertutup tersebut diberi lubang sebesar gulungan kertas;

c. Gulungan kertas yang telah berisi nama-nama anggota populasi tersebut dikocok dan dikeluarkan satu persatu sejumlah sampel yang telah ditetapkan (49 sampel );

d. Anggota sampel tiap-tiap sekolah yang telah keluar sebagai sampel ditulis kedalam lembar daftar anggota sampel penelitian.

3. Teknik Analisis Data

Adapun data yang telah dikumpulkan dianalisis dengan menggunakan teknik analisis yaitu; (a) uji persyaratan analisis meliputi uji normalitas data, uji linieritas, 
dan uji homogenitas, (b) uji hipotesis yang terdiri dari analisis regresi, analisis koefisien determinasi, uji t dan uji F. Untuk memudahkan pengolahan data, maka data diolah mengunakan komputer program Statistical Program for the Social Sciences (ssps versi 20).

\section{HASIL DAN PEMBAHASAN}

\section{Hasil Penelitian}

Hasil uji normalitas data dengan menggunakan aplikasi SPSS Versi 20 dapat diringkas sebagai berikut:

Tabel 1. Ringkasan Hasil Uji Normalitas Data

\begin{tabular}{crcll}
\hline No & Nilai Galat Taksiran & $\begin{array}{c}\text { Asymp. Sig } \\
\text { (2-tailed) }\end{array}$ & \multicolumn{1}{c}{ Hasil Uji } & \multicolumn{1}{c}{ Kesimpulan } \\
\hline 1 & Regresi Galat Y atas $X_{1}$ & 0,996 & $\begin{array}{l}\text { Tolak Ho pada } \alpha> \\
0,05\end{array}$ & $\begin{array}{l}\text { Data galat berdistribusi } \\
\text { Normal }\end{array}$ \\
\hline 2 & Regresi Galat Y atas $X_{2}$ & 0,976 & $\begin{array}{l}\text { Tolak Ho pada } \alpha> \\
0,05\end{array}$ & $\begin{array}{l}\text { Data galat berdistribusi } \\
\text { Normal }\end{array}$ \\
\hline
\end{tabular}

Berdasarkan data hasil uji normalitas tabel di atas, nilai Asymp. Sig. $=0,996$ $>0,05 \mathrm{Y}$ atas $\mathrm{X}_{1}$. Pada uji Kolmogorov-Smirnov ternyata lebih besar dari 0,05 maka data galat regresi $\mathrm{Y}$ atas $\mathrm{X}_{1}$ berdistribusi normal. Begitu juga $\mathrm{Y}$ atas $\mathrm{X}_{2}$, nilai Asymp. Sig. $=0,976>0,05$ maka data galat regresi $\mathrm{Y}$ atas $\mathrm{X}_{1}$ berdistribusi normal. Sedangkan hasil uji linieritas dengan melihat Deviation from Linearity dapat diringkas sebagai berikut:

Tabel 2. Ringkasan Hasil Uji Linieritas dengan Deviation from Linearity

\begin{tabular}{ccccl}
\hline No & Uji Linieritas & Sig. & $\alpha$ & \multicolumn{1}{c}{ Kesimpulan } \\
\hline 1 & $\mathrm{X}_{1}$ terhadap Y & 0,996 & 0,05 & $\begin{array}{l}\text { Tolak H0 terima } \mathrm{H}_{1}, \mathrm{X}_{1} \text { terhadap } \mathrm{Y} \\
\text { adalah linear }\end{array}$ \\
\hline 2 & $\mathrm{X}_{2}$ terhadap Y & 0,976 & 0,05 & $\begin{array}{l}\text { Tolak H0 terima } \mathrm{H}_{1}, \mathrm{X}_{2} \text { terhadap Y } \\
\text { adalah linear }\end{array}$ \\
\hline
\end{tabular}

Pada tabel di atas dapat diketahui bahwa nilai Deviation from Linearity $\mathrm{X}_{1}$ terhadap $\mathrm{Y}$ sebesar $0,996>0,05$. Dengan demikian tolak $\mathrm{H}_{0}$ dan terima $\mathrm{H}_{1}$, sehingga pengaruh supervisi akademik terhadap mutu pendidikan adalah linear. Begitu juga nilai Deviation from Linearity $\mathrm{X}_{2}$ terhadap $\mathrm{Y}$ sebesar 0,976 > 0,05. Dengan demikian tolak $\mathrm{H}_{0}$ dan terima $\mathrm{H}_{1}$, sehingga pengaruh kompetensi pedagogik terhadap mutu pendidikan adalah linear. Sedangkan hasil uji homogenitas dapat diringkas sebagai berikut:

Tabel 3. Ringkasan Hasil Uji Homogenitas dengan Test of Homogeneity of Variances

\begin{tabular}{ccccccc}
\hline No & Data Galat & $\begin{array}{c}\text { Levene } \\
\text { Statistic }\end{array}$ & df1 & df2 & Sig. & Kesimpulan \\
\hline 1 & Y atas $\mathrm{X}_{1}$ & 1,781 & 12 & 35 &, 091 & Varians populasi homogen \\
\hline 2 & Y atas $\mathrm{X}_{2}$ & 1,780 & 11 & 35 &, 096 & Varians populasi homogen \\
\hline
\end{tabular}

Dari tabel di atas diketahui bahwa nilai $\mathrm{Y}$ atas $\mathrm{X}_{1}$ sig. $=0,096>0,05$ pada supervisi akademik dengan mutu pendidikan, maka dikatakan bahwa data mempunyai varian yang sama. Begitu juga nilai $\mathrm{Y}$ atas $\mathrm{X}_{2}$ sig. $=0,091>0,05$ pada 
kompetensi pedagogik dengan mutu pendidikan, maka dikatakan bahwa data mempunyai varian yang sama, sehingga memenuhi syarat untuk dilakukan uji hipotesis. Setelah dilakukan anlisis regresi dapat dihasilkan uji koefesinsi $\mathrm{X}_{1}, \mathrm{X}_{2}$ terhadap Y secara parsial maupun simultan sebagai berikut:

Tabel 4. Ringkasan Hasil Uji Regresi $\mathrm{X}_{1}, \mathrm{X}_{2}$ terhadap $\mathrm{Y}$

\begin{tabular}{ccccc}
\hline Variabel & $\begin{array}{c}\text { Koefisien Regresi } \\
(\text { Beta })\end{array}$ & $\begin{array}{c}\text { Koefisien Korelasi } \\
(\mathrm{r})\end{array}$ & $\mathrm{t}$ & $\mathrm{R}$ square \\
\hline $\mathrm{X}_{1}$ & 0,266 & 0,460 & 2,055 & \\
$\mathrm{X}_{2}$ & 0,440 & 0,557 & 3,400 & 0,368 \\
\hline
\end{tabular}

Dari hasil uji regeresi pada tabel tersebut dapat digambarkan lebih rinci sebagai berikut:

a. $\mathrm{t}$ tabel pada df residual diperoleh 2,012, sehingga nilai $\mathrm{t}_{1}$ hitung $=2,055>\mathrm{t}$ tabel $=2,012$, maka ada pengaruh gaya kepemimpinan $\left(\mathrm{X}_{1}\right)$ terhadap kinerja guru $(\mathrm{Y})$ dan hipotesis diterima.

b. Nilai $\mathrm{t}_{2}$ hitung $=3,400>\mathrm{t}$ tabel $=2,012$, maka ada pengaruh partisipasi komite sekolah $\left(\mathrm{X}_{2}\right)$ terhadap kinerja guru $(\mathrm{Y})$ dan hipotesis diterima.

c. Sumbangan Efektif (SE) gaya kepemimpinan kepala sekolah $\left(\mathrm{X}_{1}\right)$, partisipasi komite sekolah $\left(\mathrm{X}_{2}\right)$ terhadap kinerja guru $(\mathrm{Y})$.

1) Sumbangan Efektif (SE) gaya kepemimpinan kepala sekolah $\left(X_{1}\right)$ terhadap kinerja guru (Y).

$\mathrm{SE}\left(\mathrm{X}_{1}\right) \%=0,266 \times 0,460 \times 100 \%$

$\mathrm{SE}\left(\mathrm{X}_{1}\right) \%=12,3 \%$

Maka pengaruh gaya kepemimpinan terhadap kinerja guru sebesar 12,3\%

2) Sumbangan Efektif (SE) partisipasi komite sekolah $\left(\mathrm{X}_{2}\right)$ terhadap kinerja guru $(\mathrm{Y})$.

$\mathrm{SE}\left(\mathrm{X}_{2}\right) \%=0,440 \times 0,557 \times 100 \%$

$\mathrm{SE}\left(\mathrm{X}_{2}\right) \%=24,5=\%$

Maka pengaruh partisipasi komite sekolah terhadap mutu pendidikan sebesar $24,5 \%$

3) Sumbangan Efektif (SE) total :

$\mathrm{SE}$ total $=\mathrm{SE}\left(\mathrm{X}_{1}\right) \%+\mathrm{SE}\left(\mathrm{X}_{2}\right) \%$

SE total $=12,3 \%+24,5 \%$

SE total $=36,8 \%$

Sedangkan pengaruh gaya kepemimpinan kepala sekolah dan partisipasi komite sekolah secara bersama-sama terhadap kinerja guru 36,8\%

d. Sumbangan Relatif (SR) gaya kepemimpinan kepala sekolah $\left(\mathrm{X}_{1}\right)$, partisipasi komite sekolah $\left(\mathrm{X}_{2}\right)$ terhadap kinerja guru $(\mathrm{Y})$ dengan total sumbangan efektif sebesar 0,368 atau sama dengan koefisiens determinasi (Rsquare) analisis regresi yakni $36,8 \%$.

1) Sumbangan Relatif (SR) gaya kepemimpinan $\left(X_{1}\right)$, terhadap kinerja guru $(\mathrm{Y})$.

$S R(X 1) \%=\frac{12,3 \%}{36,8 \%}=33,42 \%$

2) Sumbangan Relatif (SR) partisipasi komite sekolah $\left(\mathrm{X}_{2}\right)$ terhadap kinerja guru (Y).

$S R(X 2) \%=\frac{24,5 \%}{36,8 \%}=66,58 \%$

3) Sumbangan Relatif (SR) total : 
SR total $=\mathrm{SR}(\mathrm{X} 1) \%+\mathrm{SR}(\mathrm{X} 2) \%$

SR total $=33,42 \%+66,58 \%=100 \%$

Dari gambaran tersebut di atas maka dapat disimpulkan sebagai berikut:

a. Dari hasil penelitian hipotesis pertama supervisi akademik terhadap mutu pendidikan terdapat pengaruh sebesar $12,3 \%$, sehingga hipotesis tolak $\mathrm{H}_{0}$ terima $\mathrm{H}_{1}$ : yaitu ada pengaruh positif dan signifikan antara gaya kepemimpinan kepala sekolah terhadap kinerja guru.

b. Dari hasil penelitian hipotesis kedua partisipasi komite sekolah terhadap kinerja guru terdapat pengaruh sebesar $24,5 \%$, sehingga hipotesis tolak $\mathrm{H}_{0}$ terima $\mathrm{H}_{1}$ : yaitu ada pengaruh positif dan signifikan antara kompetensi pedagogik terhadap mutu pendidikan.

c. Dari hasil penelitian hipotesis ketiga gaya kepemimpinan terhadap kinerja guru secara bersama-sama terdapat pengaruh sebesar 36,8\%, sehingga hipotesis tolak $\mathrm{H}_{0}$ terima $\mathrm{H}_{1}$ : yaitu ada pengaruh signifikan antara gaya kepemimpinan kepala sekolah dan partisipasi komite sekolah secara bersama-sama terhadap mutu pendidikan.

\section{Pembahasan Penelitian}

Berdasarkan hasil uji hipotesis tersebut dapat diperoleh temuan bahwa hipotesis pertama, kedua, dan ketiga teruji. Masing-masing temuan dapat dijelaskan sebagai berikut:

a. Ada pengaruh signifikan antara gaya kepemimpinan kepala sekolah terhadap kinerja guru SMK se-Kecamatan Labuhan Maringgai sebesar 12,3\%, dan tujuan penelitian yang demikian dapat dibuktikan. Hal ini sesuai dengan pendapat Suwartini (2017: 63) yang menyatakan bahwa "Gaya kepemimpinan kepala sekolah menjunjung tinggi praktek perbaikan mutu secara berkesinambungan (continous quality improvement) sebagai salah satu prinsip dasar dan manajemen terpadu". Ini menunjukkan bahwa gaya kepemimpinan kepala sekolah sebagai salah satu cara untuk memperbaiki kinerja guru di sekolah dan menjaga kinerja guru di sekolah sehingga dapat bertahan dan berjalan secara terus menerus.

b. Ada pengaruh signifikan antara kompetensi guru terhadap terhadap mutu pendidikan SMK se-Kecamatan Labuhan Maringgai sebesar 24,5\%, dan tujuan penelitian yang demikian dapat dibuktikan Hal ini sejalan dengan pernyataan yang dikemukakan oleh Tyagita (2018: 166) yang menyatakan bahwa untuk meningkatkan kineja guru, maka kinerja guru harus ditingkatkan, salah satunya dengan meningkatkan partisipasi komite sekolah guru untuk meningkatkan kinerja guru.

c. Ada pengaruh signifikan antara gaya kepemimpinan kepala sekolah dan partisipasi komite sekolah secara bersama-sama terhadap mutu pendidikan SMK se-Kecamatan Labuhan Maringgai sebesar 36,8\%, dan tujuan penelitian yang demikian dapat dibuktikan. Hal ini membuktikan bahwa secara bersamasama gaya kepemimpinan kepala sekolah dan Partisipasi komte sekolah berpengaruh positif dan signifikan terhadap kinerja guru.

\section{KESIMPULAN}

Berdasarkan hasil analisis data yang telah didukung oleh persyaratan uji yang cukup, maka pada penelitian ini dapat ditarik kesimpulan bahwa gaya kepemimpinan 
kepala sekolah dan partisipasi komite sekolah baik secara parsial maupun simultan berpengaruh positif terhadap kinerja guru SMK Sekecamatan Labuhan Maringgai Lampung Timur. Pengaruh antara gaya kepemimpinan dan Komite Sekolah secara bersama-sama terhadap kinerja guru SMK Se-Kecamatan Labuhan Maringgai Kabupaten Lampung Timur sebesar 21,5\%.

\section{DAFTAR PUSTAKA}

Andini, Deassy M., dan Supardi, E. (2018). Kompetensi Pedagogik Guru Terhadap Efektivitas Pembelajaran Dengan Variabel Kontrol Latar Belakang Pendidikan. Jurnal Pendidikan Manajemen Perkantoran [Online], Vol. 1 No. 2, 7 halaman.Tersedia:http://ejournal.upi.edu/index.php/jpmanper/ rticle/download/9450/5840 [17 Januari 2019].

Astuti, R., dan Dacholfany, Muhammad I. (2016). Pengaruh Supervisi Pengawas Sekolah dan Kepemimpinan Kepala Sekolah Terhadap Kinerja Guru SMP Di Kota Metro Lampung. Jurnal Lentera Pendidikan Pusat Penelitian LPPM UM Metro, Volume 1 Nomor 2, 2 Desember 2016.

Daryanto, dan Rachmawati, Tutik. (2015). Supervisi Pembelajaran. Yogyakarta: Gava Media.

Direktorat Jenderal Pendidikan Dasar dan Menengah. (2017). Panduan Supervisi Akademik. Jakarta: Kementerian Pendidikan dan Kebudayaan.

Direktorat Jenderal Guru dan Kenaga Kependidikan. (2018). Modul Pengembangan Fungsi Supervisi Akademik dalam Implementasi K13 Jenang SMP. Jakarta: Kementerian Pendidikan dan Kebudayaan.

Holsinger, D.B. \& Cowell, R.N. (2000). Policies and Strategies for Secondary Education. UNESCO: International Institute for Educational Planning.

Peraturan Menteri Pendidikan Nasional No. 35 Tahun 2010 tentang Petujuk Teknik Pelaksanaan Jabatan Fungsional Guru dan Angka Kreditnya. 2010. Jakarta.

Peraturan Pemerintah No. 74 Tahun 2008 tentang Guru. 2008. Jakarta.

Sagala, Syaiful. (2017). Manajemen Strategik dalam Peningkatan Mutu Pendidikan. Bandung: Alfabeta.

Saondi, O., dan Suherman, A. (2012). Etika Profesi Keguruan. Bandung: PT Refika Aditama.

Sitepu, B.P. (2007). Prakarsa Sekolah Dalam Meningkatkan Mutu Proses Pendidikan. Jurnal Pendidikan dan Kebudayaan. Vol. 13 No. 67, 27 halaman. 
Sumayanti, Vivi., Yasir Arafat, Achmad Wahidy. (2021). Pengaruh Kepemimpinan Kepala Sekolah dan Komite Sekolah Terhadap Kinerja Guru. Jurnal Pendidikan Tambusai. Vol 5 No 1 Tahun 2021. Hal 1329-1349

Supardi. (2014). Kinerja Guru. Jakarta: PT RajaGrafindo Persada.

Tyagita, Brigitta Putri A. (2018). Strategi Peningkatan Kompetensi Pedagogik Guru untuk Meningkatkan Mutu Sekolah. Jurnal Kelola Manajemen Pendidikan [Online], Vol. 5 No. 2, 12 halaman. Tersedia: https://ejournal. uksw.edu/kelola/article/view/938 [20 Agustus 2019].

Undang-undang Republik Indonesia No. 14 Tahun 2005 tentang Guru dan Dosen. 2005. Jakarta. 